\title{
近世期の河川沿いにおける会津藩の水運施設の空間構成に関する研究 一塩川御蔵所を事例としてー
}

\section{A STUDY ON THE SPATIAL STRUCTURES OF EDO PERIOD'S RIVER SIDE WATER TRANSPORTATION FACILITIES OWNED BY AIZU DOMAIN}

- In case of Shiokawa Okura-tokoro -

\section{相模 誓 雄*}

\section{Chikao SAGAMI}

\begin{abstract}
This study focuses on the Edo period's water transportation facilities called Okura-tokoro owned and operated by a domain. The purpose of this research is to explicate the spatial structure and its functional meanings of the Shiokawa Okura-tokoro that was the main Okuratokoro in the Aizu domain. The analysis shows that Shiokawa Okura-tokoro consists of two kinds of okura-tokoro, partially common and partially different in the aspect of spatial structures. A further discussion is made on its meaning also.
\end{abstract}

Keywords : Storehouse, Premises, Spatial structure

蔵, 屋敷, 空間構成

\section{1.はじめに}

藩政時代、会津藩は、大坂一廻米を輸送するため揚川（現在の阿 賀野川及び、阿賀川）水系の水運を用いた。藩の年貢米は、廻米と して船で積み出されて揚川を川下げされ、新潟港から海路を経て大 坂へ運ばれた (図 1)。このため会津藩は、領内の河川沿いなどに御 蔵所を設けた。

揚川水系の水運を用いた廻米輸送の起点は、藩領内最大の穀倉地 帯である会津盆地の中央に位置する耶麻郡塩川村であった（図 1 ）。 同村から蒲原郡津川町までの間の揚川は、難所があり、廻米輸送は、 河沼郡上野尻村から同郡徳沢村までや、耶麻郡舘原村から同郡赤岩 村端村小ヶ峯までの間などは、陸路を用いた。一方、津川町より下 流は、全て船の航行が可能であった。この部分の水運は、藩の監督 の下、「津川船道」と呼ばれる津川町の組織が取り仕切っており、同 町が会津藩の中継港として栄えたことはよく知られるところである。 これらの村や町などの河港に廻米を納める藩の御蔵所があった。ま た、会津藩は、領内を凡そ 56 の組に分け、組毎に年貢米を集めた 1)。このため、組毎に組を構成する村々の年貢米を納める米蔵が設 けられ、これらも御蔵所と呼ばれていた。但し、その立地は、必ず しも河川沿いではなかった。

これらの御蔵所を有する村や町の中でも塩川村の河港集落は、若 松城下と米沢城下を結ぶ米沢街道の宿場町であり、若松城下に近い ためその外港的役割も果たし、物資の集散地、商業地として発展し た。従って、前述の津川町とともに会津藩の上方廻米の最も重要な

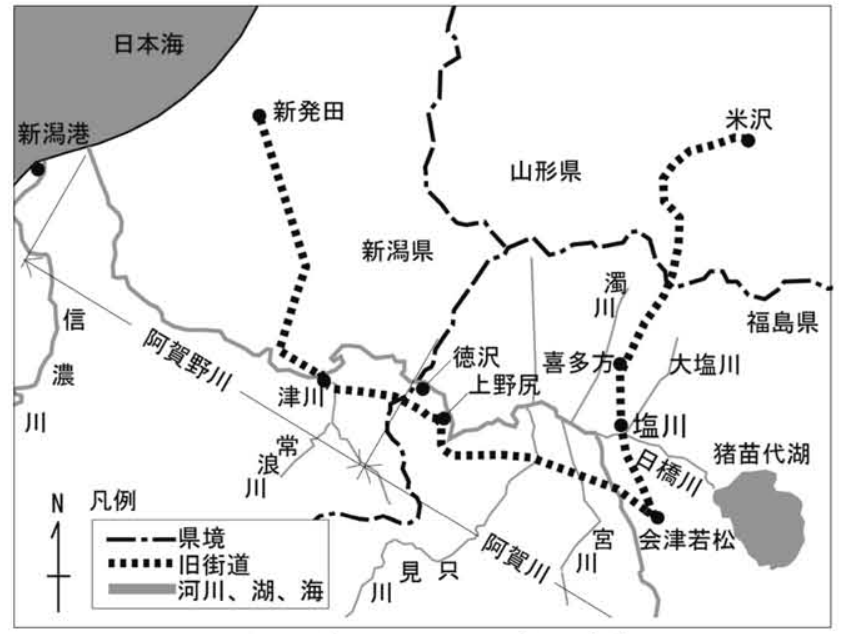

図 1 阿賀野川及び、阿賀川流域

拠点であったと考えられる。

\section{2. 研究の視点}

藩政時代の河川水運の施設に関しては、大都市における、藩の御 蔵を有する大名屋敷を取り上げた建築史学 ${ }^{2}$ や河岸地に関する史学 3)などの既往研究が見られるが、地方における、藩の水運施設であ る御蔵所の空間構成に関する研究は見られない。日本建築史研究に おいて空白の部分であり、ここに取り上げる意義がある。過去に筆

\footnotetext{
*宮城大学事業構想学部デザイン情報学科 助教・博士(工学) Assistant Prof., Dept. of Spatial Design and Information Systems, Faculty of Project Design,
} Miyagi Univ., Dr. Eng. 
者は、東北地方において、仙台藩が北上川沿いに設けた「御藏場」 のうち建物配置が知られる複数の例を対象とし、河港の機能に注目 して、空間構成の共通性とその意味についての研究論文を発表した 4)。さらに、岩木川沿いの弘前藩や最上川沿いの米沢藩の「御蔵屋 敷」についても同様な観点から検討した ${ }^{5)}$ 。一方、会津藩の場合、 建物配置が知られる例が殆どないが、前述の塩川御蔵所については 建物配置の詳細が知られ、複数の御蔵所が集合した例と見られるの で（後掲図 4)、本研究では塩川御蔵所を取り上げ、空間構成の実態 及び、意味を明らかにすることにする。

塩川御蔵所跡は住宅地に変わっており、藩政期当時の建築等は見 られない。しかし、建物配置が知られる絵図史料として、明治 6 年 (1873）の『塩川村御藏所絵図面』が現存する（後掍図 4)。本図は 明治 6 年（1873）の史料であるが、後述するように御蔵所の立地、 空間構成要素及び、蔵の数は、藩政後期の御蔵所と殆ど変わってい ないと見られるので、空間構成の検討において本図から幕末期の御 蔵所を見ても大過ないと考えられる。この御蔵所の外観が描かれる 絵図史料には、文政 10 年（1827）の『塩川町風景屏風』(図 3 ) や 文政 7 年 (1824) の塩川町を描いた『塩川町並絵図(写)』(後掲図 5 ）がある。さらに、塩川村における年貢米の納入や、备米の船で の積み出しの様子が描かれる天保年間（1830～1843）の『塩川町風 俗屏風』(後掲図 6 、図 7 及び、図 8 ) が現存する。また、会津藩は、 自らの費用で御蔵所を普請するなどして廻米事業を営んだので、御 蔵所に関する諸規定を設けている。それらは、寛永 8 年（1631）か ら文化 3 年 (1806) までの間の会津藩政の記録『家世実紀』などに 見られる。

本研究の場合、遺構調查が不可能であるため、以上の絵図や文献 を用いることの有效性が認められる。第一に、これらの史料を用い て塩川御蔵所を目的別に区分する。第二に、区分したそれぞれの御 蔵所の空間構成の実態を示す。第三に、その意味を検討し、塩川御 蔵所の空間構成について考察する。さらに、筆者がこれまで明らか にしてきた他藩の御蔵所の空間構成との比較から、東北地方の河川 沿いに設けられた諸所の御蔵所の中で、会津藩の迴米輸送に中心的 な役割を果たした塩川御蔵所を位置付けることにする。なお、対象 とする御蔵所の年代は、現存する史料から藩政後期とする。

\section{3. 塩川御蔵所の空間構成要素・施設}

図 2 は、現況地図に明治 6 年（1873）の『塩川村御蔵所絵図面』 （後掲図 4 ）の御蔵所の敷地を同じ縮尺として描いたものである。 このように御蔵所の跡地は、旧米沢街道に接する蔵小路の奥に位置 している。文政 10 年 (1827) の『塩川町風景屏風』(図 3 ) の塩川 町を見ると、南北行きの街道の西側、大塩川に面した土地などに蔵 や米俵を運ぶ人足が描かれており、この部分が御蔵所と見られる。 さらに、後掍図 4 を詳しく見ると、御蔵所の東方に旧米沢街道の家 並みが描かれている。

最初に、敷地の周囲の空間構成要素を抽出する。後掍図 4 におい て、御蔵所と旧米沢街道を結ぶ蔵小路、御蔵所と船着場を結ぶ道、 水路が見られる。また、図 3 の御蔵所には、屋敷林が描かれている。

次に、敷地内の空間構成要素を抽出する。後掲図 4 の御蔵所の敷 地は、L字型になっており、南北に長い部分 (A) と東西に長い部 分に水路によって隔てられている。後者は、さらに、東側 (B) と

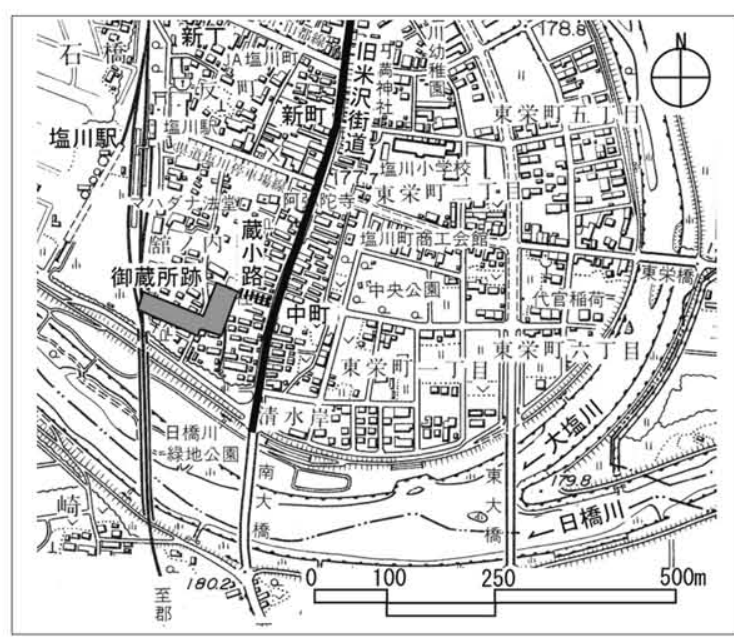

図 2 現在の福島県喜多方市塩川町中町付近

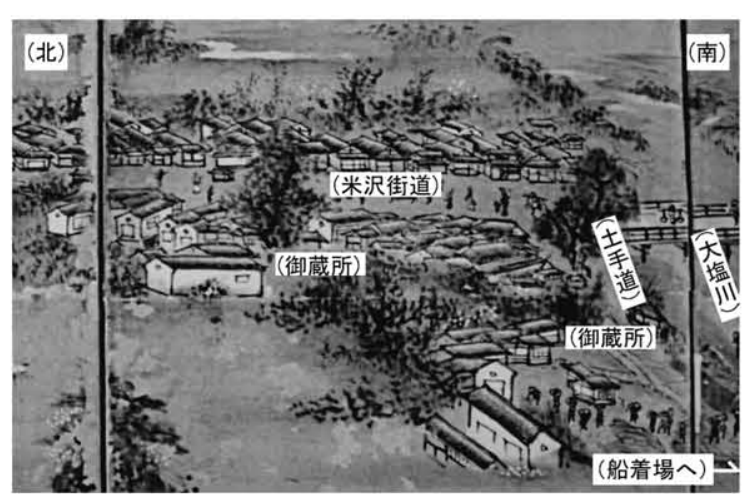

図 3 文政 10 年 (1827) の『塩川町風景屏風』のうち御藏所付近

西側（C）に二分される様子が見て取れる。(A) と（C）の部分に は、それぞれに御蔵、番屋・計屋が見られる。（B）の部分には、御 蔵、「栗村平八郎」と記された建物、御出役場が見られる。なお、栗

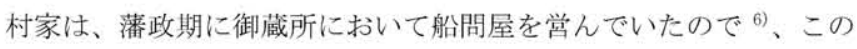
建物は、船問屋の家屋であったものと考えられる。

文政 7 年 (1824）の塩川町を描いた『塩川町並絵図 (写)』(後掲 図 5 ) において御蔵所辺りを見ると、蔵小路寄りの「口御蔵」や「御 蔵番口門」は後掍図 4 の（A）の部分に、その南西方向の「御廻米 御蔵」や「俵作役口」は（B）の部分に、その西方の「五目御蔵」 や「御蔵番伊八」は $(\mathrm{C})$ の部分に当たると見られる。

享和 3 年（1803）から文化 6 年（1809）までの間に成立した『新 編会津風土記』の塩川村の条には、「倉庵 米倉五屋 村中二二屋、 村西ニ三屋アリ、一屋八社倉ナリ、一屋八本組ノ米ヨ納メ、一屋八 五目組ノ米ヨ納メ、二屋八大坂二運漕スル米ヨ納ム、其続キ二船小 屋卜番所アリ、(後略)」と記されている ${ }^{7)}$ 。村中の 2 棟は後掲図 4 の水路より東側の $(\mathrm{A})$ の部分、村西の 3 棟は水路より西側の (B) (C) 部分の御藏と見ることができよう。前者については、後掲図 4 の（A）の部分に 3 棟の御藏が描かれているので、幕末期に御蔵 が 1 棟増えたことも知られる。

以上のことから、後掲図 4 の（A）は塩川組 24 r村の年貢米を 納めた 1 棟の御蔵、 1 棟の社倉、 1 楝の幕末期に増築された御蔵を 有する御蔵所、(C) は五目組 26 ヶ村の年貢米を納めた 1 棟の御蔵 を有する御蔵所、(B) は耶麻郡や河沼郡の 11 組の廻米を納めた 2 


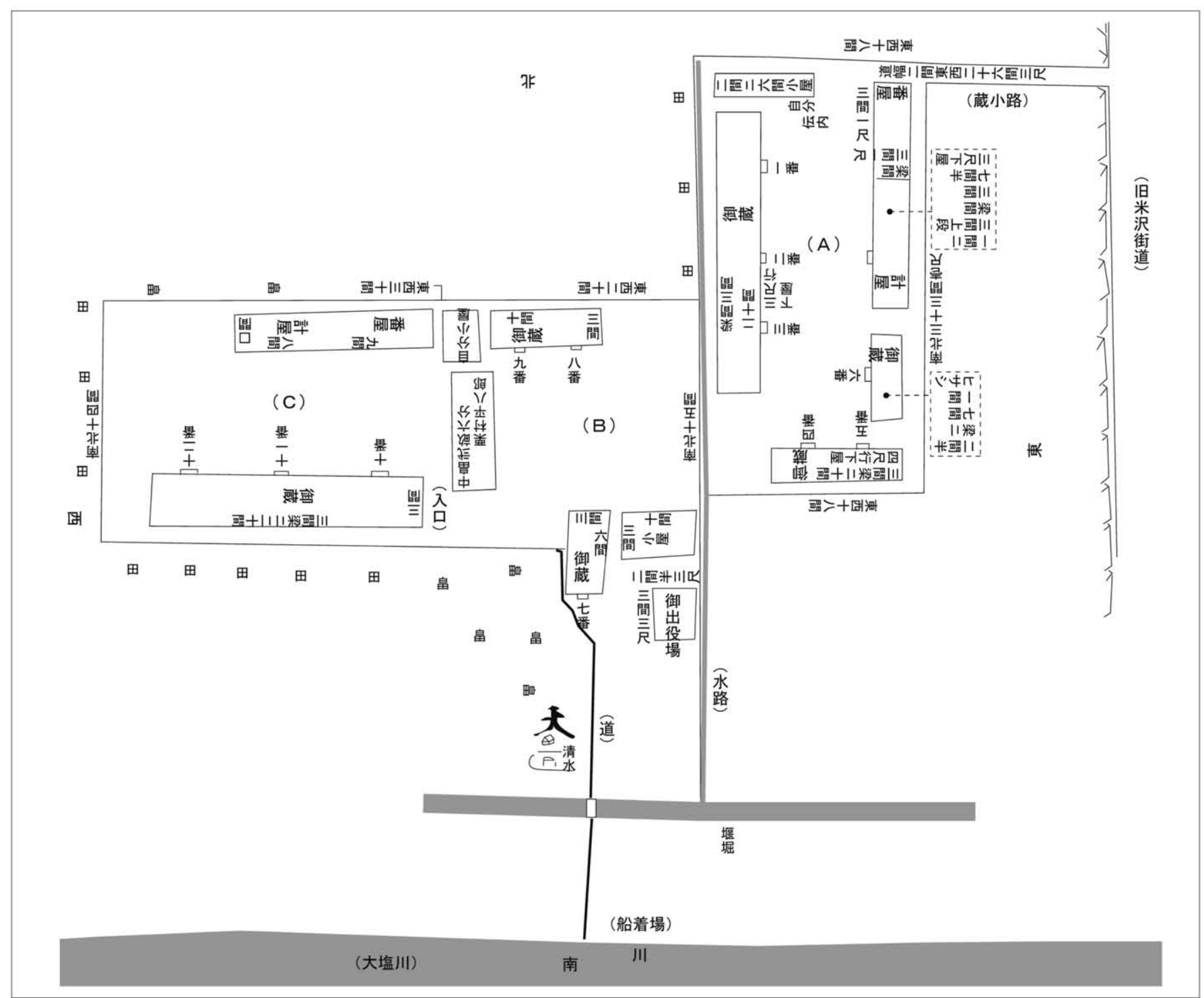

図 4 明治 6 年 (1873) の『塩川村御蔵所絵図面』

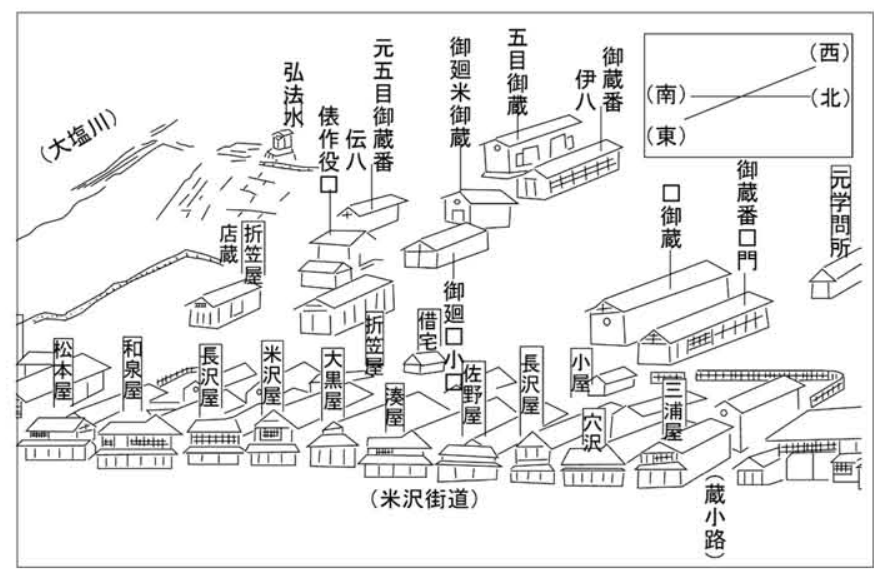

図 5 文政 7 年 (1824) の塩川町を描いた『塩川町並絵図 (写)』

棟の御蔵を有する御蔵所と考えられる。なお、社倉は、藩の制度に よる凶作に備える米を貯蔵する倉であり、およそ組毎に設けられて いた。前掲の『新編会津風土記』を見ると社倉は、塩川組の場合塩 川村などに、五目組の場合五目村に記されている。
このように塩川御蔵所は、日的の異なる 3 ケ所の御蔵所から成っ ており、年貢米を納める御蔵所と廻米を納める御蔵所とでは、主た る施設に違いが見られる。それらは、前者については御蔵、番屋・ 計屋、後者については廻米御蔵、船問屋、御出役場である。

\section{4. 塩川御蔵所の空間構成の実態}

明治 6 年 (1873) の『塩川村御藏所絵図面』(図 4) において塩川 御蔵所は、趈米を納める御蔵所に 2 ヶ所の年貢米を納める組の御蔵 所が慗がった L 字型の空間構成になっている。

\section{1 周囲の空間構成}

(1) 蔵小路、廻米御蔵所と船着場を結ぶ道

図 4 において蔵小路は、塩川組の御蔵所（A）と街道を結んでい る。その幅は「二間」と記されており、広くなっている。一方、廻 米御蔵所（B）と船着場を結ぶ道の幅は記されていないが、図の表 現から藏小路よりも狭かったことが推測される。五目組の御蔵所

（C）に慗がる道は見られない。五目組の年貢米は、後述するよう に村々から水運を用いて運ばれて来たことが考えられる。この場合、 船着場において水掦げされた米は、廻米御蔵所（B）と船着場を結 ぶ道を通って「栗村平八郎」と記される建物と御蔵との間（人口と 
考えられる) から御蔵所 (C)に運び込まれたと推定される (図 4)。

(2) 水路

図 4 において水路は、御蔵所（A）と廻米御藏所（B）の間に見 られ、御藏所 $(C)$ に見られない。

(3) 囲い・門、屋敷林

通常、藩の施設は、柵などで囲まれ門が開かれるが、塩川御藏所 の柵が記される史料は見られない。一方、門は、前掍の『家世実紀』 寛文 4 年 (1664) 五月五日の条「御収納米蔵之掟書」に、「其十、御 蔵門内江惣而飲食之類為売買二茂一切入之間敷候、(後略)」 ${ }^{8)}$ と記 されており、塩川御蔵所にもあったことが考えられる。屋敷林もあ ったが、文政 10 年（1827）の『塩川町風景屏風』(図3）のみでは 正確な樹木の位置が知られないので、空間構成の検討は難しい。

\section{2 敷地内の空間構成}

\section{(1) 御藏}

図 4の（A）（B）（C）のどの御藏所においても、御蔵は中庭を 囲んで配置されている。御蔵には、庭に面する壁面に番号が付され ており、戸前と見られる。戸前は、（A）と（C）の場合、全て中庭 一向かって開かれている。一方、(B) の場合、全て船着場へ向かっ て開かれている。

(2) 番屋 $\cdot$ 計屋

図 4 の塩川組の御藏所 $(\mathrm{A})$ において番屋部分は、人口の蔵小路 寄りに位置する。五目組の御藏所 $(\mathrm{C})$ においても番屋部分は、計 屋部分よりも人口寄りに位置する。計屋部分は、（A）（C）いずれ も番屋部分より奥に位置し、庭を挟んで御蔵に対する。

図 4 の塩川組の御蔵所 (A) の計屋内部に「一間二三間上段」と 記されている。年貢の納期には代官が御蔵所一出役したので ${ }^{9)}$ 、上 段は代官の居所と考えられる。また、前掲の『家世実紀』天明 7 年 （1787）二月廿九日の条には、計屋に上段と次の間があることが記 されている ${ }^{10)}$ 。天保年間（1830～1843）の『塩川町風俗屏風』(後 掲図 6 ）を見ると、御蔵所の街道側の出入口付近に賹床と土間を有 する建物があり、畳床部分が計屋の上段と次の間と見られる。

\section{(3) 船問屋}

図 4 の迴米御蔵所（B）において船問屋の家屋と考えられた「栗 村平八郎」と記される建物は、船着場を䚔える場所に位置し、御藏 とともに中庭を囲んでいる。

（4）御出役場

図 4 の廻米御蔵所（B）において御出役場は、御蔵よりも船着場 寄りに位置している。

\section{5. 空間構成の意味}

塩川御蔵所には、年貢米を納める御蔵所（2 所）と廻米を納め る御藏所（1 ケ所）という2 種類の御蔵所が見られたので、最初に 全体構成、次に種類毎に前章の空間構成の意味を検討することにす る。

\section{1 全体構成}

塩川御藏所の設置年は明らかでないが、明治 6 年 (1873) の『塩 川村御蔵所絵図面』(図 4) に見られる (A) 〜 (C) 3 ヶ所の御蔵 所が別々に設けられたと考えられる。慶長 13 年 (1608)、現在の位 置に米沢街道及び、塩川宿が設けられた ${ }^{11}$ 。会津藩 (松平時代) は、 寛永 20 年（1643）の保科正之の人封以来、郷頭を組の長とした郷村
支配体制を敷いた。郷頭は年貢の徵収などの業務に当った。このこ とから塩川組の御蔵所（A）は、会津藩政初期に既存の宿場町の町 裹に整備されたものと推測される。揚川水運を用いた会津藩の上方 廻米は、後述するように貞享年間（1684～1687）に始まった。この 頃に廻米御蔵所（B）が船着場に面し、かつ、（A）に隣接した土地 に設けられたと推測される。五目組の御蔵所（C）が塩川村に設け られた経緯や時期は明らかでないが、街道や河岸に直接繋がってい ないことから、(C) が最後に設けられたと推測される。なお、(C) は五目組用であるので、土地取得の優先順位は低かったものと考え られる。

（1）L字型の敷地の意味

上記の各御蔵所の成り立ちを踏まえて $\mathrm{L}$ 字型の敷地の意味を、土 地的条件や管理運営の観点から検討寸る。御蔵所は、河川沿いに形 成される平地の中に存在したので、その立地は、洪水時に有利な微 高地がよかったと考えられる。図 4 の（A）部分は、町に沿ってお り、現在の跡地の標高は町屋敷とほぼ同じである。一方、(B) (C) 部分の跡地の標高は (A) 部分よりやや低い。なお、図 4 の (C) 部分の河川側に「田」が見られる。このような土地的条件であるの で、 3 力所の御蔵所全てを微高地に配置することを優先したのであ れば、L字型の敷地形状では無理があると思われる。

また、図 4の（A）と（B）部分は、前述したように必然的にそ の位置が決定されてものと考えられるが、(C) 部分の土地はどうや って決定されたのだろうか。(C)に納められる年貢米は迴米として （B） 一運ぶ必要があった。物資運搬の効率上（C）は（B）に接 して設ける心゙きである。その位置としては、(B) の北隣と西隣が考 えられる。前者の場合、 (A) や (B) を通らないと (C) 一行き着 くことができない。後者の場合、川岸側から（B）の中心部を通ら ずに（C）へ行き着くことができる。このため、L字型の敷地にな ったと考えられる。

つまり、L字型の敷地は、御蔵所の管理運営上の効率性を意味す ると考えられる。

（2）水路の意味

図 4 において水路は、(A) と（B）の御蔵所を隔てているが、踏 板によって人足の移動は可能と考えられる。その水は、両方から利 用することができる。町場では大火が発生しやすかった。(A) 部分 は町屋敷に接しているので町場の大火において類焼する可能性が高 い。一方、(C) 部分は町屋敷から離れていた。また、東北地方の他 藩の御蔵所では、敷地内に防火用の池を設けた例があった ${ }^{12)}$ ここれ らのことから、この水路の用途の一つとして町場の大火に備えた防 火用水が考えられる。

\section{2 年貢米を納める御蔵所}

（1）蔵小路の幅の意味

享保 19 年 (1734) の『野沢与河井村御趗米道筋奉言上帳』に、「一 御藏場所口本田畠二御座候、御取合之上御竿御除被下度奉存候、尤 其筇畠方之内二御座候道幅せまく御座候、広ク被仰付度奉存候」と 記されている ${ }^{13)}$ 。年貢米の納人時期の御蔵所付近の道は、背に振り 分け荷をつけた䭾馬（後掲図 6 ）で混雑した。つまり、塩川組の御 蔵所の蔵小路が二間の道幅を必要としたのは、駄馬による年貢米の 運搬を意味すると考えられる。 
（2）御藏の配置及び、戸前の向きの意味

年貢米は御蔵に収納された。このため、御藏の戸前の辺りには米 俵の置き場が必要であったと推察される。つまり、御蔵が中庭を囲 み、戸前が中庭に面して設けられるのは、年貢米の運び入れを意味 すると考えられる。

また、図 4 の塩川組の御蔵所（A）を見ると、御蔵が中庭を囲ん で配置されることによって、向かい合う戸前と戸前との間の距離が 保たれている。天保 14 年 (1843) の会津藩領上野尻村蔵番に関する 書付に、「一出火之節防方八旸論早速土戸引、近火二も御座候八、目 塗等仕可申候、と記されており ${ }^{14)}$ 、御蔵は土藏であっても、火災 時に戸前から類焼する恐れがあったことがわかる。このため御蔵と 御蔵とを離して設ける必要があった。つまり、御蔵が中庭を囲む配 置は、御蔵の防火も意味寸ると考えられる。

\section{(3) 番屋の配置の意味}

御蔵の米は盗まれることがあったので、藏番を配置して監視させ た ${ }^{15)}$ 。また、『家世実紀』慶安 2 年 (1649) 九月晦日の条「御収納 米請払メリ筋被仰出、」に、「(前略) 其三、百姓若悪米致持参候八、 勿論米見之者下代撰出之刻、其米令印符蔵番之者二預ケ置、翌日御 代官罷出御徒目付衆引加、下代米見之者与可遂吟味候、(後略)」と 記されている ${ }^{16)}$ 。のように蔵番は、御蔵所の実質的な管理者で あり、年貢米の受け人れに関する業務も行った。つまり、番屋が入 口寄りに位置するのは、年貢米の受け人れを意味すると考えられる。 なお、町蔵 ${ }^{17)}$ の蔵番については、享和 2 年 (1802) に廃止されたが、 『家世実紀』同年六月七日の条に、「(前略) 町蔵々番被相止候二付 而八、与力之内より成とも蔵方勤之者并米致出人候小者、是又壱蔵 一壱人つ〉無之者相成間敷（後略）」と記されており ${ }^{18}$ 、代わりの 者が配置されている。

\section{(4) 計屋の配置の意味}

宝暦 8 年 (1758) の『御用御触留書覚書』に、「古来八寅御収納八 不及申、割收納之内たり共、遠郷八勿論近郷共二、夜之内八つ七つ 比より宿出致候、御蔵所一八未明より段々相詰候故、早朝より升を 立候二付、自俵作少等并御蔵入とも二果敢行、(後略)」と記されて おり ${ }^{19)}$ 、年貢米が御蔵所へ運び込まれると先ず升目改めが行なわれ た。また、計屋においては、米見（米の品質の検查）が行なわれた ${ }^{20)}$ 。つまり、計屋が庭を挟んで御蔵に対するのは、検查後の年貢米 を御蔵に運び人れたことを意味すると考えられる。

\section{3 廻米を納める御蔵所}

\section{（1）廻米御蔵所と船着場を結ぶ道の幅の意味}

文政 10 年 (1827) の『塩川町風景屏風』(図 3 ) には、御藏所か ら船着場までの間に米俵を担ぎ一列に並んだ人足たちが描かれてい る。つまり、迴米御蔵所と船着場を結ぶ道の幅が蔵小路の幅よりも 狭く見られるのは、人力による廻米（米俵）の運搬を意味すると考 えられる。

\section{（2）御蔵の配置及び、戸前の向きの意味}

塩川村の迴米御蔵所に納められる迴米は、揚川及び、支流日橋川 の右岸方面の、塩川組を含む北方 7 組と、同左岸方面の、青津組、 牛沢組、坂下組、笈川組から運ばれた。前者のうち五目組や慶徳組 は、濁川水運によって塩川村へ通じていた。その下り荷物は、米な どであった ${ }^{21)}$ 。また、後者のうち前 3 組は、揚川で塩川村と隔てら れていたので、廻米が船で運ばれてきたことが考えられる ${ }^{22)}$ 。一方、
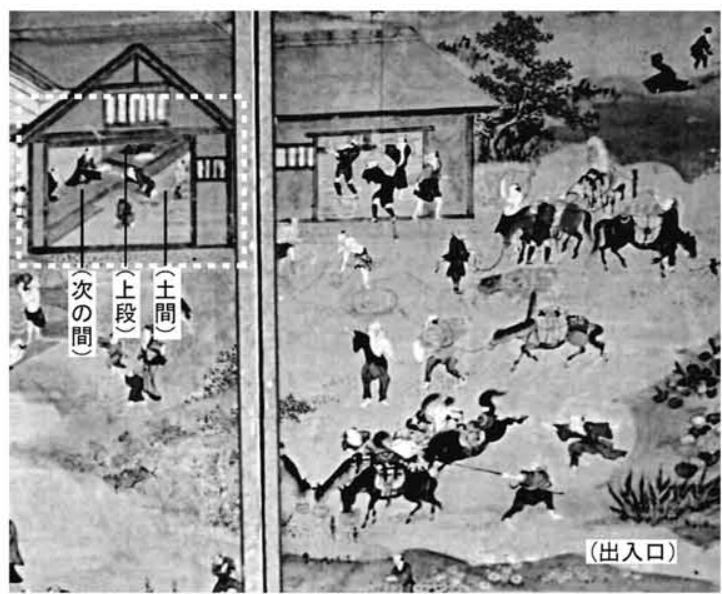

図 6

6 天保年間（1830～1843）の『塩川町風俗屏風』のうち、計屋 付近
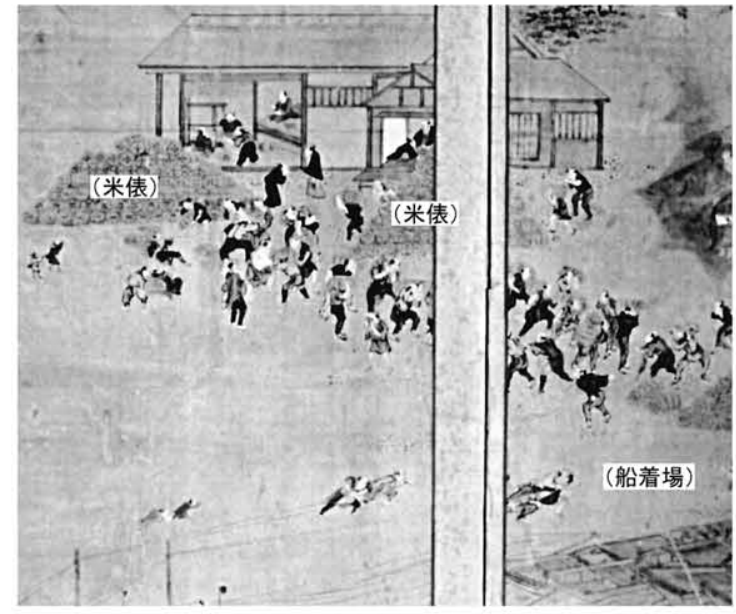

図 7 『塩川町風俗屏風』のうち、御出役場付近

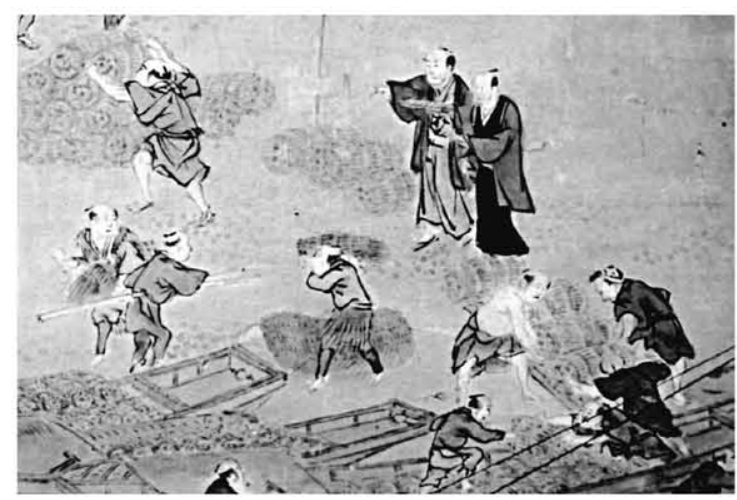

図８『塩川町風俗屏風』のうち、船着場部分

これら以外の地域は駄送になるが、その運び人れ経路は、図 4 の街 道から蔵小路に人り、塩川組の御蔵所 $(\mathrm{A})$ を通って迴米御蔵所 $(\mathrm{B})$ へ至るものと、街道から図 3 に描かれる川岸部分の土手道に人り、 土手道を通って迴米御藏所 $(\mathrm{B})$ 一至るものが考えられる。前者は、 （A）と（B）の間に水路もあり考えにくい。従って、後者の経路 が利用されたものと推測される。いずれにしても廻米は船着場側か ら運び込まれたと考えられる。御蔵の廻米を船での積み出す時は、 米俵が御蔵から船着場へ運ばれた。つまり、御蔵の戸前が船着場へ 
向かって開かれるのは、迴米の運び人れ及び、船での積み出しを意 味すると考えられる。御蔵が中庭を囲む意味については前述した。

(3) 船問屋の配置の意味

塩川村の船問屋栗村家は、貞享年間（1684～1687）に自ら揚川の 水運航路を開発し、藩の廻米輸送を請負った ${ }^{23)}$ 。このため米の管理 も自ら行っていたものと考えられる。つまり、船問屋の家屋が、船 着場を窥える場所に位置し、中庭を囲むのは、船問屋による廻米の 運営及び、御蔵の防犯を意味すると考えられる。従って、塩川村の 廻米御蔵所に番屋は必要なかった。

（4）御出役場の配置の意味

図 4 の御藏所における御出役場の位置は、文政 7 年（1824）の塩 川町を描いた『塩川町並絵図 (写)』(図 5 ) の御蔵所関係の建物群 における「俵作役 $\square 」 の$ 位置と大よそ一致する。なお、备米所の役 人は、村々の御蔵所において廻米用の米俵の検分行なった ${ }^{24)}$ 。この ことから御出役場は、廻米用の米俵の検分時に使用された役場と考 えられる。天保年間 $(1830 \sim 1843)$ の『塩川町風俗屏風』の川岸に 面した場所に、積み上げられた米俵や曽床を有する建物が描かれて おり、御出役場と見られる(図 7 )。

御藏に納められた廻米は「出所場」と称する船着場へと運ばれて 船で川下げされた。塩川御蔵所には、廻米を船で積み出す際、その 業務を監督する章領が派遣されていたと推測される ${ }^{25)}$ 。天保年間 （1830～1843）の『塩川町風俗屏風』には、船着場において米俵の 船への積み込み作業を監督、指図する宰領や船問屋と見られる人物 が描かれている（図 8)。しかし、宰領が御出役場を使用した記録は 見られない。

以上のことから御出役場は、迴米所の役人が使用した施設と考え られる。つまり、御出役場が御蔵より船着場寄りに位置するのは、 廻米所の役人による、村々より運び込まれる迴米（米俵）の検分を 意味すると考えられる。

図 9 は、以上の塩川御蔵所の空間構成を図化したものである。

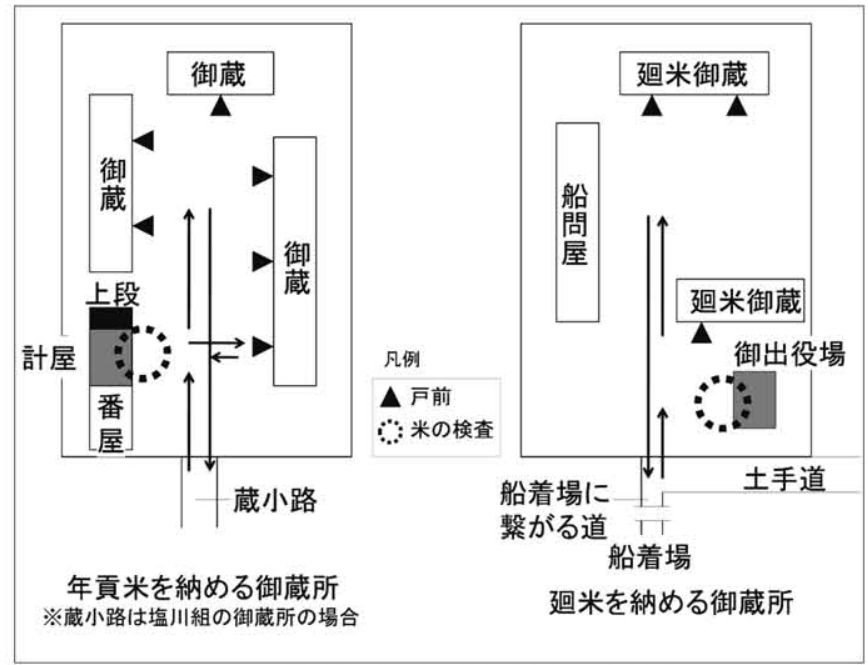

図 9 塩川御藏所の空間構成の分析図

\section{6. まとめ}

本研究によって、藩政後期の河川沿いに設けられた会津藩の塩川 御蔵所の空間構成に関して、以下のことが明らかになった。
塩川御蔵所が、塩川組と五目組の年貢米を納める御蔵所、1 1 組 の廻米を納める御蔵所という目的の異なる 3 ケ所の御蔵所から成っ ていたことを示した。また、塩川組の年貢米を納める御蔵所には、 塩川村の社倉や幕末期に増築された御蔵の存在も推測された。

年貢米を納める、塩川組の御蔵所（A）と五目組の御蔵所（C） の主たる空間構成要素・施設は、周囲については（A）の場合、街 道に慗がる蔵小路、水路であった。敷地内についてはいずれも御蔵、 番屋・計屋（上段、次の間、土間）であった。廻米を納める御蔵所 （B）の主たる空間構成要素・施設は、周囲については船着場に慗 がる道、水路であった。敷地内については御蔵、船問屋、御出役場 であった。なお、門、屋敷林については、存在したことが考えられ たが、実態を明らかにすることはできなかった。

塩川御蔵所の全体構成は、廻米を納める御蔵所に 2 ヶ所の年貢米 を納める組の御蔵所が慗がった L 字型の敷地になっていた。その意 味は御蔵所の管理運営上の效率性にあると考えられた。町場寄りの

（A）と（B）の御藏所の間に水路が通っており、その意味の一つ に御藏所の防火が考えられた。

年貢米を納める 2 ヶ所の御蔵所の空間構成は、いずれも御蔵が中 庭を囲んで配置され、全ての戸前が中庭に面していた。その意味は 年貢米の運び人れ及び、御蔵の防火であった。また、一棟の建物で ある番屋と計屋は、番屋が計屋より敷地の人口寄りに位置した。そ の意味は番人による年貢米の受け入れであった。一方、計屋は、中 庭を挟んで御蔵に対していた。その意味は検査後の年貢米を御蔵に 運び入れたことであった。さらに、塩川組の年頁米を納める御蔵所 については、蔵小路を有し、その幅は 2 間と広かった。その意味は 駄馬による年貢米の運搬であった。

廻米を納める御蔵所の空間構成は、御蔵が中庭を囲んで配置され る点は年貢米を納める御蔵所と同じであるが、全ての戸前が船着場 へ向けて設けられた点が異なっている。この空間構成の意味が廻米 の運び入れ及び、船での積み出しであったことから、戸前の向きは、 船着場との関係から決定されたことが考えられる。さらに、次の点 も廻米を納める御蔵所に固有の空間構成と言える。船問屋が船着場 を窥える場所に位置し、御蔵とともに中庭を囲んでいた。その意味 は船問屋による迴米の運営及び、御蔵の防犯であった。御出役場が 御蔵より船着場寄りに位置していた。その意味は廻米所の役人によ る廻米（米俵）の検分であった。船着場と廻米御蔵所を結ぶ道の幅 は狭く見られた。その意味は人力による廻米（米依）の運搬にあっ た。

以上、会津藩の場合、河川水運による廻米輸送にも陸運を併用せ ざるをえない事情があり、このために迴米を留め置く専用の御蔵所 が設けられた。従って、塩川御蔵所では年貢米と廻米は御蔵所を分 けて保管され、両者の御蔵所の空間構成には異なる部分が多くあっ た。その原因は、両者の間で船着場との関係性、空間構成要素及び、 その機能、物資の運搬手段が異なったことにあると考えられる。但 し、両者は、管理運営上の効率性の面から見ると、密接不可分の関 倸になっていたと思われる。このような機能分化した会津藩の塩川 村における御蔵所は、筆者がこれまで明らかにしてきた前述の東北 地方の河川沿いにおける他藩の御蔵所には見られない特殊な例とし て位置付けられる。 
注

1）「新編会津風土記」，享和 3 年（1803）～文化 6 年（1809）会津潾は、 領内の村々を凡そ 56 組に分けて年貢米の収集を行なうなど、郷村支配体 制を整えた。なお、郡とは異なる。

2)大坂などの大名屋教にも米蔵が設けられ、蔵屋敷と呼ばれていた。植松清 志氏らは、佐贺藩大坂蔵屋敖の建築構成や御屋形の変遷について述へてい る。(植松清志、中嶋節子、谷直樹 : 佐賀藩大坂蔵屋教について, 日本建築 学会計画系論文集, 第 530 号, pp. 221〜227, 2000.4）この大名屋敨である蔵 屋敷は、本研究が対象とする御蔵所とは目的や業務内容などが異なる。

3) 小林信也 : 近世江戸町方の河岸地についてー新肴場河岸地を事例に一, 史学 雑誌, 第 103 編第 8 号, pp. 58〜85, 1994.8

4) 相模誓雄・飯淵康一・永井康雄: 仙台藩領北上川流域の集落における御蔵場 に関する研究一路村を中心として一, 民俗建築, 第 130 号, pp. 15〜 24, 2006. 11

5) 相模誓雄: 近世期の最上川沿い米沢藩御蔵屋教の空間構成に関寸る研究, 日 本建築学会計画系論文集, 第 641 号, pp. 1655 1660, 2009.7

6)会津若松史出版委員会編: 会津若松史 3, 会津若松市, 1965, p. 313

7)「新編会津風土記巻之五十四」（新編会津風土記第 3 巻, 歴史春秋出 版, 2001, pp. 58～59 所収）, 享和 3 年（1803）～文化 6 年（1809）

8)「家世実紀巻之二十五」(会津藩家世実紀第 2 巻, 吉川弘文館, 1976, p. 167 所 収)

9)「家世実紀巻之二百二十七」（会津藩家世実紀第 12 巻, 吉川弘文 館, 1986, p. 609 所収） 本書の天明 7 年（1787）二月廿九日の条に、「(前 略）此外御代官蔵々一罷出候節、召仕候者無之候間、(後略)」と記されて いる。

10)前掲 9）「家世実紀巻之二百二十七」本書に、「(前略) 立入之者蔵々計 屋へ罷出候節、上段之次之間一罷出可申哉之旨伺候間、(後略)」と記され ている。

11) 塩川町史編㔍委員会編: 塩川町史, 塩川町, 1966, p. 98

12) 東北地方建設局岩手工事事務所 : 北上川第 6 輯, 1977, p. 361 本書におい て、仙台潘の「下川原御本穀御蔵地割絵図」に描かれる池について、「防火 用水池」と述べられている。

13)「石本雄也家文書」(塩川町史第 4 巻, 喜多方市, 2007, p. 861 所収)

14)「石本雄也家文書 乍恐以苦付御受奉差上候」(西会津町史第 4 巻 (中), 西 会津町史刊行委員会, 1995, p. 584 所収) , 天保 14 年 (1843)

15)「石本雄也家文書 乍恐以曺付奉御披露候」(西会津町史第 4 巻 (中), p. 585 所収), 嘉永元年 (1848) 本書に、「当村領分中嶋御㢠米御蔵二御囲米多 分御座候二付、村中迴り二尽夜番人附置申候処、昨夜何者之仕業二御座候 哉御蔵武つ之内板蔵之西之方戸板 7 破置候趣、(中略) 右破候所上り盗取候 物と相見一申候二付、(後略)」と記されている。

16)「家世実紀巻之九」(会津藩家世:実紀第 1 巻, 吉川弘文館, 1975, p. 334 所収)

17）「町蔵」は、町場に設けられた御蔵所の呼称か。

18）「家世実紀巻之二百六十五」（会津藩家世実紀第 15 巻, 吉川弘文 館, 1989, p. 233 所収)

19）「外島道雄家文苦 御用御触留苦覚苦」（塩川町史第 4 巻, p. 536 所収）

20)前掲 9)「家世実紀巻之二百二十七」本書の天明 7 年 (1787) 二月廿九 日の条に、「(前略) 次之間八下代罷出候場所二而、蔵番とも八用事有之節 はかり呼出候事二而候故、下代米見一之立入二候八、別格、藏番入立入候 儀二而八次之間一罷出候筋有之間数、(後略)」と記されている。

21) 喜多方市史編纂委員会編 : 喜多方市史第 2 巻, 喜多方市, 1997, p. 441

22) 青津組については、文久 3 年（1863）の『青津御蔵限物請払帳』に、「五 百九拾六俵 本途残川蔵為登」と記されており、米が川沿い人運ばれてい た。また、坂下組については、坂下御蔵所付近を流れる旧宮川に水速があ ったことが伝えられている。

23)前掲 11）塩川町史編箱委員会編: 塩川町史, pp. 112 114

24）「家世実紀巻之百九十九」（会津藩家世実紀第 11 巻, 吉川弘文 館, 1985, p. 342 所収) 本書の明和 8 年 (1771) 正月廿三日の条「迴米方之 者共出役先慎方申渡、」に、「(前略) 於地下方も為俵作立合并俵作役人郷村 一罷出候節、止宿之村方肝煎遠見を出圈、案内等致候由無用之事二候、（後 略)」と記されている。
25)「栗村冲家文書 舟運準備の件」(塩川町史第 4 巻, p. 888 所収) 武井善 右衛門が塩川村権七郎へ宛てた書状に、「(前略) 舟積之節八此方より御米

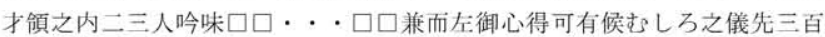
枚追可申候 (後略)」と記されている。

\section{図版出典}

図 1、9 筆者作製

図 2 喜多方市『塩川町全図』(縮尺一万分の一) を用いて筆者が作製した。 御蔵所の政地の長さは、図 4 に拠る。

図 3 個人藏, 文政 10 年 (1827)

本屏風絵には、塩川町及び、その周辺の景観が描かれている。御蔵所は、 大まかに描かれているが、町場における御蔵所の位置や、御蔵所の周囲の 検討には十分に足りると考えられる。

喜多方市所有の写真に、（）の文字を追記した。

図 4 福島県歴史資料館蔵, 庄司家寄託文書

本図に作製年は記されていない。しかし、本図は、明治 6 年（1873）に 大沢駅陸運会社の前田耕作が若松県権令人申請した廻漕会社設立のための 関倸資料であり、庄司家文書では、明治 6 年 (1873) の史料になっている。 土地や各施設の長さが記されており、当時の御蔵所の実態を正確に描いた ものと考えられる。

原図の写真をトレースし、（）の文字を追記した。

図 5 喜多方市藏

原図の作製年については、本写図に「これは文政七年に代官所に届出た 軒別圖」と記されている。

本図には、町場の建物の外観が一軒一軒詳しく描かれている。敷地は描 かれていない。建物には、屋号と当主の名 (省略)、名称が記されており、 建物の把握に主眼を置いて描かれたものと推察される。

写図の写真をトレースし、（）の文字、方位を追記した。

図 6、7、8 栗村潔氏蔵

作製年代は、天保年間（1830～1843）と伝えられている。

本屏風絵には、塩川村における行事の様子、街道を往来する人々、御蔵 所の建物や敖地内で仕事をする人々が詳しく描かれている。 喜多方市所有の写真に、（）の文字等を追記した。

（2009年11月 6 日原稿受理，2010年 3 月 29 日採用決定） 